\title{
AN ARGUMENT FOR CLOSER COOPERATION BETWEEN THE EUROPEAN UNION AND THE COUNCIL OF EUROPE IN THE FIELD OF EU ENLARGEMENT REGULATION
}

\begin{abstract}
Dimitry Kochenov*
Summary: Judging by the Copenhagen-related documents that regulated the preparation of the $5^{\text {th }}$ enlargement of the European Union, the role played by the Council of Europe in the pre-accession was only minimal. This paper poses a question whether it would be beneficial to continue regulating enlargements along the same line. Alternatively to the presently adopted practice, the Council of Europe, which has its own effective system of human rights protection monitoring, might be invited to play a more active role in the preparation of the enlargements to come, which would make the application of the principle of conditionality more effective. Such a development would be in line with the recent moves towards closer cooperation between the two organisations and, especially, the Guidelines on the Relations between the Council of Europe and the European Union, appended to the Council of Europe Warsaw Summit Action Plan (2005), the recommendations contained in the recent Junker Report on the European Union - Council of Europe relations and the conclusions of the Brussels European Council (2006).
\end{abstract}

\section{Introduction}

The European Union (EU) and the Council of Europe (CoE) have rightly been called "natural born twins". ${ }^{1}$ Putting fundamental differences aside, it is evident that the two, born more or less at the same time, ${ }^{2}$ share a number of important goals, created both in order to serve the development of Europe and to deal with the aftermath of the cataclysms of the first half of the $20^{\text {th }}$ century. Notwithstanding an attempt de facto

\footnotetext{
" Lecturer in European Law, University of Groningen. The author would like to thank Fabian Amtenbrink, Gareth Davies, Laurence Gormley and an anonymous reviewer for their comments on some ideas expressed in the article, and also Siniša Rodin for the kind invitation to present the first draft at the seminar 'Advanced Issues of European Law' in Dubrovnik in the spring of 2005.

${ }^{1}$ G von Toggenburg, 'A Remaining Share or a New Part? The Union's Role vis-à-vis Minorities after the Enlargement Decade' (EUI Working Papers, Law No. 2006/15), 23 <http:// cadmus.iue.it/dspace/bitstream/1814/4428/1/LAW+2006.15.pdf> accessed 18 September 2006.

${ }^{2}$ The CoE was created on 5 May 1949. See CoE Statute, ETS no. 001. The European Coal and Steel Community Treaty was signed in Paris on 18 April 1951 and entered into force on 23 July 1953.
} 
to eliminate the then young European Coal and Steel Community by incorporating it into the $\mathrm{CoE}$ under the Eden Plan, ${ }^{3}$ the relations between the $\mathrm{CoE}$ and $\mathrm{EU}$ are constructive and friendly. Cooperation between them has been growing in recent years and is expected to grow even further. ${ }^{4}$ The European Council has been optimistic on this issue. ${ }^{5}$ After all, the two organisations also share a number of Member States: membership of the $\mathrm{CoE}$ has always largely coincided with that of the Communities.

The fall of the Berlin Wall and the deterioration of the dictatorial regimes in the East of the European continent offered an historic opportunity to both the EU and the $\mathrm{CoE}$ to put the division of Europe to an end and to extend their membership to the ex-communist states. The drastic changes taking place in Europe at the end of the last century did not only have an impact on the geographical scope of the jurisdiction of the twins in question. They also provided an impetus for the development of European integration. ${ }^{6}$ Clearly, it seems to be no coincidence that the Wall fell in 1989 and that the EU was born with a Treaty signed in $1992 .^{7}$

Both organisations were enlarging at a truly unprecedented pace. Since the beginning of the 1990s, the EU has welcomed 13 new Member States $^{8}$ (and also expanded to include the territory of the former German Democratic Republic ${ }^{9}$ ), which more than doubled the number of the

\footnotetext{
${ }^{3}$ Under the plan, the ECSC Institutions were to become subdivisions of the CoE's Committee of Ministers and Consultative Assembly and were to be served by the CoE secretariat: F Duchêne, Jean Monnet, The First Statesman of Interdependence (W.W. Norton \& Co., New York /London 1994) 237.

${ }^{4}$ See, for example, Annex 1 'Guidelines on the Relations between the Council of Europe and the European Union' to the Document of the Third Summit of Heads of State and Government of the Council of Europe, Warsaw, 16 - 17 May $2005<$ http://www.coe.int/t/ dcr/summit/20050517_plan_action_en.asp> accessed 18 September 2006; JC Juncker, 'Council of Europe - European Union: "A Sole Ambition for the European Continent" (Report by Jean-Claude Juncker, Prime Minister of the Grand Duchy of Luxembourg, to the attention of the Heads of State or Government of the Member States of the Council of Europe) 11 April 2006 <http://assembly.coe.int/Sessions/2006/speeches/20060411_report_JCJuncker_EN.pdf> accessed 18 September 2006.

${ }^{5}$ Presidency Conclusions, Brussels European Council, 16 June 2006, para 58.

${ }^{6}$ T Judt, Postwar: A History of Europe since 1945 (The Penguin Press, New York 2005) 3.

${ }^{7}$ WT Eijsbouts, Het verdrag als tekst en als feit: De wedergeboorte van het Europese recht uit het vallen van de Berlijnse Muur (Vossiupers UvA, Amsterdam 2002) esp. at 29.

8 Including Austria, Sweden, Finland (Treaty of Accession 1994 [1994] OJ C241. See also Adaptation Decision [1995] OJ L1), Estonia, Latvia, Lithuania, Poland, the Czech Republic, Slovakia, Hungary, Slovenia, Cyprus and Malta (Treaty of Accession 2003 [2003] OJ L236). For an analysis of this Treaty, see K Inglis and A Ott, 'EU-uitbreiding en Toetreidingsverdrag: verzoening van droom en werkelijkheid' (2004) 52 (20) SEW 4; K Inglis, 'The Union's Fifth Accession Treaty: New Means to Make Enlargement Possible' (2004) 41 CML Rev 937; E Lannon, 'Le traité d'adhésion d'Athènes: Les négociations, les conditions de l'admission et les principales adaptations des traités resultant de l'élargissement de l'UE à vingt-cinq Etats membres' (2004) 40 CDE 15.

${ }^{9}$ Extending EU jurisdiction to the territory of the former DDR is not counted as a separate round of enlargement since it was regulated by German law, not by the EU enlargement
} 
Member States it had before 1989. The CoE was enlarging even faster. As many as 23 countries have joined the CoE since the beginning of 1990 .

The enlargement saga is far from over, however. While the $\mathrm{CoE}$ is likely to see the accession of Montenegro in the nearest future, ${ }^{10}$ the EU will embrace two other states (Bulgaria and Romania) already in $2007^{11}$ and more will join later on. Three countries currently enjoy candidate country status, including Croatia, Macedonia (FYROM) and Turkey. ${ }^{12}$ Moreover, a number of countries in Europe, Africa and the Caucasus have made it clear that accession to the EU is among their main foreign policy objectives. These countries include Albania, Armenia, Bosnia and Herzegovina, Cape Verde, ${ }^{13}$ Georgia, Montenegro, ${ }^{14}$ Moldova, Serbia and Ukraine. ${ }^{15}$ A number of other States, such as San-Marino, ${ }^{16}$ are studying the possibilities of joining. Among the countries of Eastern Europe (not counting Russia), only Belarus under the rule of president Lukashenka is not expressing any membership ambitions. ${ }^{17}$ All in all, while the $\mathrm{CoE}$ seems to have largely used all its enlargement possibilities, the European Union stands somewhere in the middle of its enlargement road - in the future, enlargements are likely to stay on the agenda of the EU for several decades at least.

instruments: M Bothe, 'The German Experience to Meet the Challenges of Reunification' in AE Kellermann, JW de Zwaan and J Czuczai (eds), EU Enlargement: The Constitutional Impact at EU and National Level (T.M.C. Asser Press, The Hague 2001).

${ }^{10}$ Montenegro received international recognition as an independent state following the split of the State Union of Serbia and Montenegro as a result of the referendum of 21 May 2006.

11 Subject to the Commission's approval. The date of accession can be moved to 2008. See Treaty of Accession 2005 [2005] OJ L157.

${ }^{12}$ Two of these countries (Croatia and Turkey) have already started accession negotiations.

${ }^{13}$ AFP, 'Cape Verde Could Seek EU Membership this Year', EU Business (7 May 2005) <http://www.eubusiness.com/Portugal/050507114923.9ivv9852> accessed 18 September 2006.

14 The desire of the State Union of Serbia and Montenegro to join the EU was so articulated that three out of six goals outlined in the State Union's Constitutional Charter were related to European integration: S Samardži and D Lopandi , 'Serbia and Montenegro' in $\mathrm{AE}$ Kellermann and others (eds), The Impact of EU Accession on the Legal Orders of New EU Member States and (Pre)Candidate Countries: Hopes and Fears (T.M.C. Asser Press, The Hague 2006) 149.

${ }^{15}$ See Ministerstvo Zakordonnykh Sprav Ukraïny, 'Stratehija intehratzï Ukraïny do Jevropejs'koho Sojuzu' 08 June 1998 <http://www.mfa.gov.ua/mfa/ua/publication/content/2823.htm> accessed 18 September 2006.

${ }^{16}$ Republic of San Marino, Secretariat of Foreign Affairs, 'Aide Mémoire' $2<$ http://www. europa.eu.int/comm/external_relations/sanmarino/doc/aidememoire.pdf> accessed 18 September 2006.

17 The outcast regime is building a "State Union" with the Russian Federation instead: VV Elistratova, 'Pravovyje aspekty v sfere integratzii Rossii i Respubliki Belarus" (2005) 8 Pravo i gosudarstvo 117. 
It is not among the goals of this article to provide a detailed account of the accession law of the two organisations. ${ }^{18}$ Instead, the paper will explore the role played by the monitoring of the level of human rights protection in the course of the preparation of accession to the EU and the $\mathrm{CoE}$, and the instruments available in the law of the two organisations to make such monitoring effective. This article suggests that the human rights monitoring conducted by the EU was strongly influenced by the monitoring of the same countries by the $\mathrm{CoE}$, and welcomes such developments. Clearly, the expertise of the $\mathrm{CoE}$ in the field of human rights protection, and especially in the area of standard setting, is undisputed. ${ }^{19}$ Viewed in this light, it is suggested that the EU would only benefit if, in the course of the preparations for future enlargements, it openly relied on the findings of the $\mathrm{CoE}$ and tried to incorporate the $\mathrm{CoE}$ monitoring into the pre-accession assessment of the candidate countries' readiness to accede to the Union. Although the warm relations between the CoE and the EU allow us to speculate that such developments might become legally possible, at present the Community institutions are not obliged to build on the CoE findings while regulating enlargements. At the same time, while such an obligation is lacking, given the flexible nature of the regulation of the pre-accession exercise as established during the last enlargement, ${ }^{20}$ it would be reasonable to suggest that taking the $\mathrm{CoE}$ monitoring results on-board would reflect the human rights commitment of the Community institutions and would not be contrary to Community law. The development of human rights cooperation between the EU and the $\mathrm{CoE}$ in the regulation of future enlargements is thus strongly advocated and highly recommended.

\footnotetext{
${ }_{18}$ On the enlargement law of the CoE, see, for example, H Klebes , 'Membership in International Organisations and National Constitutional Law: A Case Study of the Law and Practice of the Council of Europe' (1999) 99 St. Louis-Warsaw Transatlantic LJ 69. On the enlargement of the EU, see most importantly A Ott and K Inglis (eds), Handbook on European Enlargement (T.M.C. Asser Press, The Hague 2002). Cf. D Kochenov, 'EU Enlargement Law: History and Recent Developments: Treaty - Custom Concubinage?' (2005) 9(6) EIoP (with an exhaustive list of books on this issue in $\mathrm{n} \mathrm{2)} \mathrm{<http://eiop.or.at/eiop/texte/2005-006.htm>}$ accessed 18 September 2006; J Kundera (ed), Rozszerzenie Unii Europejskiej: Korzyści i koszty dla nowych krajów cztonkowskich (Wydawnictwo Uniwersitetu Wrocławskiego, Wroclav 2005); Ch Hillion (ed), EU Enlargement: A Legal Approach (Hart, Oxford /Portland 2004).

${ }^{19}$ On the standard setting role of the $\mathrm{CoE}$ see, for example, MC Kettemann, 'A Soft Law Reality Check: Reflections on the Role and Influence of Council of Europe Expert Bodies on Standard-Setting in European Human Rights Law with Special Reference to Normative Impacts of the Czech Republic' (2006) 2 Hanse LR 106 <http://www.hanselawreview.org/ pdf3/Vol2No1Art08.pdf> accessed 18 September 2006.

${ }^{20}$ On such flexibility, see, for example, D Kochenov, 'EU Enlargement: Flexible Compliance with the Commission's Pre-Accession Demands and Schnittke's Ideas on Music', (CSEP Working Paper, Centre for the Study of European Politics and Society, Ben-Gurion University of the Negev 2005) <http://hsf.bgu.ac.il/europe/index.aspx?pgid=pg_127842651974615376> accessed 18 September 2006.
} 


\section{Structure of the argument}

This paper consists of four sections. The first one briefly outlines the changes introduced into the EU enlargement law in the course of the preparation of the last enlargement in order to illustrate the rising importance of the assessment of the human rights situation in the candidate countries. This section also provides a sketch of the EU preaccession monitoring of the candidate countries' progress towards accession, including their adherence to the principle of the protection of human rights (I). The second section focuses on the structure of the $\mathrm{CoE}$ monitoring system, also discussing the parallels between the $\mathrm{CoE}$ human rights monitoring of the new members and the EU monitoring of the candidate countries' human rights record (II). The third section explores the difficulties encountered by the Community institutions in the field of the pre-accession human rights standard setting. It underlines the importance of the role played by the CoE. The latter organisation has actually acted in the capacity of a standard provider for the Commission, especially in the areas lying outside the scope of the acquis communautaire (III). Building on the assumption that the $\mathrm{CoE}$ monitoring standards and findings played a prominent role in the preparation of the last enlargement of the EU, the last section of the paper draws parallels

between the $\mathrm{EU}$ and $\mathrm{CoE}$ monitoring in some concrete fields, providing tangible examples of areas where $\mathrm{CoE}$ standards were actually used by the EU. These examples are concerned both with the general structuring of the pre-accession human rights monitoring conducted by the Commission and the (partial) use by the EU of some issue-specific standards developed by the CoE (IV).

The paper concludes by stating that the similarities between the goals of the two organisations, coupled with the principled positions both of them take vis-à-vis the protection of human rights in Europe, will help to make the EU pre-accession exercise more effective by linking the human rights monitoring of the candidate countries conducted by the Community institutions on the one hand, with the findings of the $\mathrm{CoE}$ on the other hand. Careful analysis of the pre-accession monitoring conducted by the Commission during the preparation of the last enlargement clearly demonstrates that such borrowing of human rights standards and findings by the Community has already started. Any developments related to the legal incorporation of the $\mathrm{CoE}$ monitoring findings into the $\mathrm{EU}$ enlargement law will thus build on the existing practice and are likely to have a positive effect on the development and functioning of the EU enlargement law at large. 


\section{The role of human rights protection in the EU enlargement law}

The first enlargement of the EU (then the three Communities) did not accord any crucial importance to human rights protection. ${ }^{21}$ Just as in the case of democracy and the rule of law, ${ }^{22}$ human rights were not on the agenda mainly for two reasons: the main accent was placed on the economic nature of the Communities, ${ }^{23}$ and it was presumed that the national human rights protection systems of the first three applicants (the UK, Denmark and Ireland) were functioning well enough in order to assure effective human rights protection. Later enlargements, although crucially different from the first one in many respects, did not grant importance to an assessment of human rights protection either.

However, the fifth (2004) enlargement was a notable exception in this regard. Both presumptions allowing the Communities to disregard the importance of human rights protection in the course of the preparation of the previous enlargements largely did not hold for the fifth enlargement. Between the first and the beginning of the preparations for the fifth enlargement, very much had changed.

Most importantly, the European integration project ceased to be viewed exclusively as an economic enterprise and was seen to embrace the principles of "liberty, democracy, respect for human rights and fundamental freedoms". ${ }^{24}$ The language of rights became more easily accepted at the European level of governance; moreover, a special mechanism was built into the Treaty to guarantee that the Member States continued adhering to the main democratic and human rights principles. ${ }^{25}$ The active position of the ECJ, ${ }^{26}$ Treaty revisions, and other matters, such as

\footnotetext{
${ }^{21}$ Academic literature dealing with enlargement issues did not focus on the issue of human rights either. See ME Bathurst and others (eds), Legal Problems of an Enlarged European Community (Stevens and Sons, London 1972); P Uri, La Grande-Bretagne rejoint l'Europe: du Commonwealth au Marché Commun (Plon, Paris 1967).

${ }^{22}$ For an analysis of the substance and structure of democracy and the rule of law criterion, see D Kochenov, 'Behind the Copenhagen Façade: The Meaning and Structure of the Copenhagen Political Criterion of Democracy and the Rule of Law' (2004) 8 (10) EIoP passim <http://eiop.or.at/eiop/texte/2004-010a.htm> accessed 18 September 2006.

${ }^{23}$ GF Mancini, Democracy and Constitutionalism in the European Union (Hart, Oxford /Portland 2000) 31.

${ }^{24}$ Treaty on European Union, art 6(1)

25 Treaty on European Union, art 7.

${ }^{26}$ For example, Case 29/69 Erich Stauder v City of Ulm - Sozialamt [1969] ECR 419 para 7; Case 11/70 Internationale Handelsgesellschaft mbH v Einfuhr- und Vorratstelle für Getreide und Futtermittel [1970] ECR 1125; Case 4/73 J. Nold, Kohlen- und Baustoffgroßhandlung v Commission [1974] ECR 491. For an analysis of the role of the ECJ in the process, see, for example: JR Wetzel, 'Improving Human Rights Protection in the European Union: Resolving the Conflict and Confusion between the Luxembourg and Strasbourg Courts' (2003) 71 Fordham LR 3834; HG Schermers and DF Waelbroeck, Judicial Protection in the European Communities (6th ed Kluwer, The Hague /London /New York 2001) 38-46.
} 
the legal articulation of the EU citizenship concept, ${ }^{27}$ all played a role in underlining the importance of human rights in the EU legal system. Consequently, such a crucial rise in importance of the human rights protection ideals for the European integration project obviously could not but bring significant innovations to the European Union enlargement law. ${ }^{28}$

The second presumption concerning the sufficient guarantees of human rights protection in the national legal orders of the Member States also largely lost its appeal. This mostly occurred as a result of the EU's fear "to go to bed with bad guys", as Jan Klabbers put it, ${ }^{29}$ and thus owes much to the important transformation brought to Europe by the ending of the Cold War. Simply put, the EU lacked trust in the depth of transformation in Central and Eastern European countries (CEECs) and needed to be constantly reassured of the fundamental character of the change taking place in the region. Although it has been argued that the loss of trust might be a signal of the end of the "old-days' integration" based on the "feeling of Community" and brotherhood, ${ }^{30}$ it would have been overtly naïve to expect the Union to embrace new members whose human rights record and democratic future were vague and unstable.

In other words, the changes in the EU enlargement law, incorporating the assessment of the human rights protection record of the candidates, were caused by two sets of objective factors: the evolution of the European Union itself, and the nature of the applicants for membership - i.e. post-communist states in transition.

The change in the EU enlargement law which was aimed at responding to the aforementioned developments did not focus exclusively on human rights. It incorporated the overall assessment of the candidate

\footnotetext{
${ }^{27}$ European Community Treaty, Part II and ECJ case-law, e.g. Case C-85/96 Maria Martínez Sala v Freistaat Bayern [1998] ECR I-2691; Case C-184/99 Rudy Grzelczyk v Centre public d'aide sociale d'Ottignies-Louvain-la-Neuve [2001] ECR I-6193; Case C-413/99 Baumbast and R. v Secretary of State for Employment, [2002] ECR I-7091; Case C-148/02 Carlos Garcia Avello v Belgian State [2003] ECR I-11613; Case C-200/02 Kunqian Catherine Zhu and Man Lavette Chen v Secretary of State for the Home Department [2004] ECR I-9925. On the controversial misuse of the concept in the course of enlargement, see D Kochenov, 'The European Citizenship Concept and Enlargement of the Union' (2003) 3 Romanian J. Pol. Sci 71 <http://ssrn.com/abstract=926850> accessed 18 September 2006.; D Kochenov, 'European Integration and the Gift of Second Class Citizenship' (2006) 13 Murdoch U. Electronic JL 209 <https://elaw.murdoch.edu.au/issues/2006/1/eLaw_Kochenov_13_2006_12.pdf> accessed 18 September 2006.

${ }^{28}$ Formally, a reference to art 6(1) EU was introduced into art 49 EU regulating enlargement.

${ }^{29} \mathrm{~J}$ Klabbers, 'On Babies, Bathwater and the Three Musketeers, or the Beginning of the End of European Integration' in V Heiskanen and K Kulovesi (eds), Function and Future of European Law (Proceedings of the International Conference on the Present State, Rationality and Direction of European Legal Integration) (Publications of the Faculty of Law University of Helsinki, Helsinki 1999) 279.

${ }^{30}$ Ibid
} 
countries' progress in basically all the spheres of reform. The EEC's relations with the CEECs entered an active phase immediately after the revolutions in the former COMECON states, ${ }^{31}$ when the first Europe (Association) Agreements were signed. ${ }^{32}$ The first sign of new policy appeared in the form of the famous Copenhagen criteria: ${ }^{33}$ the Conclusions of the Copenhagen European Council 1993 made the prospects of accession dependant on the achievement of compliance with this vague standard, concerning both the political and economic development of the candidate countries, thus introducing the principle of conditionality into the enlargement process. Viewed by scholars mostly as a political document, the Copenhagen criteria gained new importance and entered the legal field of enlargement regulation once the enhanced pre-accession strategy started to be implemented. ${ }^{34}$

The policy of stick and carrot, aimed at the "preparation" of the candidate countries for membership of the EU, combined EU financial assistance $^{35}$ with a strict link established between the performance of the

${ }^{31}$ For a brilliant analysis of the EU - CEECs relations, see KE Smith, The Making of EU Foreign Policy: The Case of Eastern Europe (2nd ed Palgrave Macmillan, Basingstoke 2004). Cf. F de la Serre, 'A la recherche d'une Ostpolitik' in F de la Serre, C Lequesne, J Rupnik (eds), L'Union européenne : ouverture à l'Est? (PUF, Paris 1994).

${ }^{32} \mathrm{~F}$ Hoffmeister, 'Nature and Objectives of the Europe Agreements' in A Ott and K Inglis (eds) (n 18) 349; K Inglis, 'The Europe Agreements Compared in the Light of Their Pre-Accession Reorientation' (2000) 37 CML Rev 1173; E Tucny, L'élargissement de l'union européenne aux pays d'Europe centrale et orientale: La conditionnalité politique (L'Harmattan, Paris /Montréal 2000) 89.

${ }^{33}$ Presidency Conclusions, European Council (Copenhagen, 21-22 June 1993) [1993] EC Bull supp. 6.

${ }^{34}$ L Beurdeley, L'élargissement de l'Union européenne aux pays d'Europe centrale et orientale et aux îles du bassin méditerranéen (L’Harmattan, Paris /Montréal 2003) 43; Ch Hillion, 'Enlargement of the European Union: A Legal Analysis' in A Arnull and D Wincott (eds), Accountability and Legitimacy in the European Union (OUP, Oxford 2002) 414; K Inglis, 'The Pre-Accession Strategy and the Accession Partnerships' in A Ott and K Inglis (eds) (n 18).

${ }^{35}$ Mainly through the PHARE programme (applying to Poland, Hungary (Council Regulation (EEC) 3906/89 [1989] OJ L375/11), GDR, Czechoslovakia, Bulgaria, Romania, Yugoslavia (Amending Council Regulation (EEC) 2698/89 [1990] OJ L257/1), Albania, Estonia, Lithuania, Latvia (Council Regulation (EEC) 3800/91 [1991] OJ L357/10), Slovenia (Council Regulation (EC) 2334/92 [1992] OJ L227/1), Croatia (Council Regulation (EC) 1366/95 [1995] OJ L133/1, suspended in 1995) and FYROM (Council Regulation (EC) 463/96 [1996] OJ L65/3)); SAPARD programme, providing assistance in the agricultural sector (Council Regulation (EC) 1268/1999 [1999] OJ L161/87) and ISPA programme, providing assistance in the fields of transport and environment (Council Regulation (EC) 1267/1999 [1999] OJ L161/73). PHARE, SAPARD and ISPA are united in a single legal framework, (Council Regulation (EC) 1266/1999 [1999] OJ L161/68). See also Council Regulation (EC) 622/98 [1998] OJ L85/1 introducing Accession Partnerships and making the receipt of the pre-accession aid conditional on pre-accession progress. See also A Guggenbühl and M Theelen, 'The Financial Assistance of the European Union to its Eastern and Southern Neighbours: A Comparative Analysis' in M Maresceau and E Lannon (eds), The EU's Enlargement and Mediterranean Strategies: A Comparative Analysis (Palgrave, Basingstoke 2001); H de Chavagnac, 'Le programme PHARE d'appui aux réformes économiques dans les PECO: l'exemple des pays baltes' (1996) 369 Revue du marché commun et de l’Union européenne 569. 
candidates and the prospects to continue benefiting from the financial assistance and, most importantly, the very prospect of entering the EU in the future. ${ }^{36}$ This crucial link, making the Copenhagen criteria de facto a legal instrument, was articulated in the Accession Partnerships (APs). ${ }^{37}$ Moreover, the Commission was entrusted with conducting the regular monitoring of the candidate countries' compliance with the Copenhagen criteria and meeting the priorities set in the APs.

As a result of these developments, a whole system of monitoring the candidates' progress was set up by the EU, making the legal framework of the fifth enlargement quite unique in EU history. Never before was the Union so intrusive in the national reforms going on in the candidate countries, especially in matters where it usually does not possess any competences, lying partially or entirely outside the scope of the acquis communautaire. ${ }^{38}$ However, all these changes largely did not find any reflection in the Treaty text, increasing the gap between the enlargement law and enlargement practice, in place since the first enlargement, which makes it possible to speak about the birth of the customary enlargement law of the EU. ${ }^{39}$

In the field of human rights, the pre-accession strategy built on the Copenhagen political criterion, requiring the candidate countries to put the systems of protection of human rights in place and to assure respect for and protection of minorities within their borders. Further on, this paper will confine itself to deal solely with this particular aspect of preaccession, since it is the field best comparable to the core activities of the CoE.

The issues considered by the European Commission as relevant for pre-accession are discussed in the Copenhagen-related documents. ${ }^{40}$ These documents, adopted by the Commission and the Council in the implementation of the Copenhagen criteria, are thus at the core of the EU monitoring of the candidate countries' progress.

They include the Commission's Opinions of the CEECs' applications for membership of the EU, the Commission's Annual Reports on the candidate countries' progress towards accession, the Comprehensive Monitoring Reports adopted by the Commission regarding the progress made

\footnotetext{
${ }^{36}$ For doubts about this strictness, see D Kochenov (n 20).

37 Council Regulation (EC) 622/98 [1998] OJ L85/1, adopted on the basis of art 308 EC, see especially art 4 of the Regulation.

${ }^{38}$ On the scope of the concept, see Ch Delcourt, 'The Acquis Communautaire: Has the Concept Had Its Day?' (2001) 38 CML Rev 829.

39 Cf. D Kochenov (n 18).

${ }^{40}$ For the structure of the whole body of the Copenhagen-related documents, $i$. e. documents released in implementation of the conditionality principle of the Copenhagen criteria, see D Kochenov (n 22) 5-8.
} 
by the candidate countries after the signing of the Accession Treaty but before its entry into force, the Commission's Papers summarising the findings of the reports and framing the future developments in the candidate countries, and the Accession Partnerships, released in the form of Council Decisions.

A structural analysis of all these instruments reveals that, in dealing with human rights and respect for and protection of minorities, the Commission divided all the issues into three main parts: Civil and Political Rights, Economic and Social Rights, and Minority Protection. The criticism of the substance of this division and the inclusion of minor issues into one of these three categories, which seems to be quite spontaneous, ${ }^{41}$ deserves separate assessment and will not be dealt with here. Focusing on the issues considered by the EU to be problematic, the Copenhagen-related documents present a narrower picture of the assessment of human rights protection than the list of rights included, for example, in the ECHR or the Charter of Fundamental Rights of the EU. ${ }^{42}$ For example, they do not contain separate assessments of dignity ${ }^{43}$ or the right to life. ${ }^{44}$

Such a position can partly be explained as follows. Firstly, there is no reason to include in the pre-accession assessment the list of rights which are not widely violated in the candidate countries. Secondly, with a view to the absence of a Union human rights policy, ${ }^{45}$ and taking into account the fragmented character of human rights protection in the EU, ${ }^{46}$

\footnotetext{
${ }^{41}$ To provide one example, in the course of regular reporting, the Commission was constantly unsure where to put the assessment of freedom of religion. In approximately half of the Reports it is considered as a civil and political right, while in the other half it is seen as an economic, social and cultural right.

42 [2000] OJ C364/01. The Charter is a "proclaimed document" having no binding force in EC law. Nevertheless, the ECJ and the Court of the First Instance made several references to the Charter: e.g. Case C-540/03 Parliament v Council [2006] of 27 June 2006, nyr; Case T-177/01 Jégo-Quéré \& Cie SA v Commission [2002] ECR II-2365 para 42.

43 Charter Title I.

${ }^{44}$ ECHR art 2; Charter art 2.

${ }^{45}$ Alston and Weiler argued for its necessity. See Ph Alston and JHH Weiler, 'An "Ever Closer Union" in Need of a Human Rights Policy: The European Union and Human Rights' in $\mathrm{Ph}$ Alston (ed), The EU and Human Rights (OUP, Oxford 1999). For further details on the human rights protection in the EU, see for example, G de Búrca, 'The Case for an EU Human Rights Policy' in C Lyons and N Walker (eds), Convergence and Divergence in European Public Law (Hart, Oxford /Portland 2002); A von Bogdandy, 'The European Union as a Human Rights Organisation?: Human Rights and the Core of the European Union' (2000) 37 CML Rev 1307; K Lenaerts, 'Fundamental Rights in the European Union' (2000) 25 ELR 6.

${ }^{46}$ According to the ECJ, the European Union does not have general competence in the field of human rights protection. See Opinion 2/94 on Accession by the Community to the ECHR [1996] ECR I-1759. Unsuccessful attempts to incorporate the protection of fundamental rights into the Treaties were made in the European Defence Community Treaty of 27 May 1952 (art 3) and the European Political Community Treaty (see the reports by the ad hoc
} 
the Commission was probably restrained by the lack of internal human rights competence ${ }^{47}$ while formulating the areas of pre-accession assessment in the field of human rights. ${ }^{48}$ Such a position is not surprising considering the at times dubious human rights record of the ECJ, ${ }^{49}$ as well as the lack of standards the Commission could apply in the course of the pre-accession. ${ }^{50}$ Thus, given the law of the day and the numerous responsibilities related to the conduct of enlargement lying on the Commission, probably the best option for it was to interpret the human rights pre-accession criterion as narrowly as possible.

The above-mentioned considerations notwithstanding, it could be argued that it might be necessary at least to mention that the EU is willing to protect and promote a wider scope of human rights than those mentioned in the Copenhagen-related documents. Moreover, the European Court of Human Rights in Strasbourg (ECtHR) heard cases coming from candidate countries that dealt, for example, with the violation of the right to life. This can be regarded as proof that in some countries the situation is not ideal even in the case of the most basic rights, especially regarding the situation of ethnic and other minorities. ${ }^{51}$

The set of rights on which the Commission was focusing was, however, quite wide and included: the freedom of expression and independence of the media; access to a lawyer; discrimination against homosexuals; human rights violations related to pre-trial detention and the situation in prisons; equality; freedom of religion.

\footnotetext{
Assembly of 26 February 1953), in arts 2 and 3. The protection of Human Rights is not even among the objectives of the Union, as clarified in art 2 EU. $C f$.D McGoldrick, 'The EU after Amsterdam: An Organisation with General Human Rights Competence?' in D O'Keeffe and P Twomey (eds), Legal Issues of the Amsterdam Treaty (Hart, Oxford /Portland, 1999) 255-256.

${ }^{47}$ In the sphere of human rights protection, external competences are much broader than internal ones: Ph Alston and JHH Weiler (n 45) 8; A Clapham, 'A Human Rights Policy of the European Community' (1990) 10 Ybk Eur L 309.

48 At present, the situation in the field of human rights is changing rapidly. Weiler and Alston's arguments have been heard, it seems: the Commission advocated the creation of the EU Fundamental Rights Agency. See COM (2005) 280 final. However, the envisaged powers of the Agency to be created on the basis of art 308 EC leave much to be desired.

${ }^{49}$ For example Case C-249/96 Lisa Jacqueline Grant v South-West Trains Ltd. [1998] ECR I-62 1, or Case 12/86 Meryem Demirel v Stadt Schwäbisch Gmünd [1987] ECR 3719. On the anti-human rights nature of the former case, see N Bamforth, 'Sexual Orientation Discrimination after Grant v South-West Trains' (2000) 63 MLR; on the nature of the latter, see JHH Weiler, 'Thou Shalt Not Oppress a Stranger: On the Judicial Protection of the Human Rights of Non-EC Nationals - A Critique' (1992) 3 Eur. J. Int'1 L. 1.

50 See III. infra.

${ }^{51}$ Assenov and others v. Bulgaria (App no 24760/94) (1998), annotated by E. Banach, 'The Roma and the Native Americans: Encapsulated Communities within Larger Constitutional Regimes' (2002) 14 Fla. J. Int'l L., 379. .
} 
To summarise, EU enlargement law as it stands before the sixth enlargement (to accept Bulgaria and Romania ${ }^{52}$ ) empowers the EU to check the level of compliance of the candidate countries with the human rights protection ideal, set, first of all, by the Copenhagen political criterion. In order to assure the effectiveness of such compliance, regular monitoring of the human rights situation in the candidate countries has been conducted by the Commission and the Council, as part of the pre-accession programme.

Importantly, with a view to the progressive legal essence of the last enlargement - building on the principle of conditionality - and the nature of the present candidate countries and likely applicants, which are all countries in the process of recovery after violent conflicts, or which are in transition as they deal with their totalitarian past, it is perfectly clear that conditionality and human rights monitoring as a necessary part of enlargement preparation are here to stay. It is very unlikely that the EU would take a step back and return to a looser enlargement regulation, which was in place before the former People's Democracies started to join.

\section{CoE monitoring system}

The EU is not the only, and arguably not the most important, actor dealing with human rights protection on the European continent. Leadership in this area belongs to the CoE, established solely for the purpose of human rights protection. Faced with the same challenges in accepting as Members the former totalitarian countries, the CoE, just like the EU, has adopted a monitoring programme, which is essentially similar to that implemented in the course of pre-accession by the EU, although a number of crucial differences can also be seen. Most importantly, CoE monitoring largely starts after the accession of the country in question to the CoE. This strategy allows the $\mathrm{CoE}$ to use the whole spectrum of legal and political tools to influence the human rights policy of the country in question. ${ }^{53} \mathrm{Un}$ like in the case of the EU, where all the candidate and associated countries largely remain outside the ECJ's jurisdiction, ${ }^{54}$ since the acquis only com-

${ }^{52}$ Some scholars and the Commission regard the upcoming round of enlargement as the continuation of the fifth round. It seems illogical, however, given that a new Treaty of Accession has been drafted for Romania and Bulgaria, making a clear case for the accession of these two countries to be regarded as the sixth round of enlargement.

${ }^{53}$ The Communities used to apply similar strategies in relation to the economic development of the candidates. Greece, for example, entered the Communities even though the review of the Greek economy made by the Commission contained largely negative assessments.

${ }^{54}$ Which is confined to dealing with Association Agreements and Partnership Agreements. See, for example, Case C-265/03 Igor Simutenkov v Ministerio de Educación y Cultura and Real Federación España [2005] judgement of 12 April 2005, nyr; Case C-416/96 Nour Ed- 
mences to apply to them from the date of accession, ${ }^{55}$ the $\mathrm{CoE}$ monitoring after accession allows new member countries to be monitored as full members of the club and thus the ECtHR also becomes an active participant in the process. Besides the ECtHR, CoE monitoring is conducted by the Parliamentary Assembly (PACE), the Committee of Ministers (CM CoE) and a number of specific organs created to monitor the state of play regarding concrete human rights violations. In other words, the $\mathrm{CoE}$ monitoring system is at least as sophisticated as the one applied by the EU. Crucially, $\mathrm{CoE}$ monitors the compliance of full members with their obligations, unlike the EU which solely measures the candidates' progress.

\section{a. PACE monitoring system}

The Commission's Reports that preceded the fifth enlargement contain information on the instances where the Parliamentary Assembly of the CoE takes a decision to stop the monitoring of a certain EU candidate country, ${ }^{56}$ regarding this information as a positive development on the way to accession. These brief accounts deserve close study, since they refer to the outcomes of a monitoring exercise which is, as stated earlier, in many ways similar to that conducted by the Commission, although it is exclusively focused on the issues related to the protection of human rights. Acknowledging the successful completion of such monitoring in relation to the candidate countries, the Commission approves of the job done by the $\mathrm{CoE}$ and in a way relies on the results obtained by this organisation. Although the closure of the monitoring procedure by the $\mathrm{CoE}$ is probably not among the strict requirements the candidate countries have to satisfy before accession, CoE monitoring plays an important part in the pre-accession process (even though this importance is not underlined by the Commission).

Having had monitoring functions for many years, ${ }^{57}$ PACE's role in the promotion of the $\mathrm{CoE}$ member countries' compliance with the obligations stemming from CoE membership increased significantly after the

dline El Yassini v Secretary of State for Home Department [1999] ECR I-1209; Case 12/86 Meryem Demirel v Stadt Schwäbisch Gmünd [1987] ECR 3719.

${ }_{55}$ For example, Case C-464/98 Westdeutsche Landesbank Girozentrale v Friedrich Stefan and Republik Österreich [2001] ECR I-173.

${ }^{56}$ European Commission, 2000 Bulgarian Report, 19; 2002 Estonian Report, 28; 2002 Latvian Report, 27. All the Regular Reports issued by the European Commission are available online at <http://www.europa.eu.int/comm/enlargement/index_en.htnl> accessed 18 September 2006..

57 Orders Nos. Dir 485 and Dir 488 (1993) and Resolutions Res. 917(1989) and Res. 1031(1994). Cf. Council of Europe, Commission pour le respect des obligations et engagements des Etats membres du Conseil de l'Europe (Commission de suivi), [AS/Mon/Inf (2004) 02 rév.], available at <http://assembly.coe.int/Mainf.asp?link=http\%3A//assembly.coe. int/committee/MON/Role_F.htm> accessed 18 September 2006. 
adoption of the Declaration of the Committee of Ministers of the CoE on the Compliance with Commitments Accepted by Member States of the CoE. ${ }^{58}$ In implementing the Declaration, Order No. 508 "On the Honouring of Obligations and Commitments by Member States of the Council of Europe" was adopted ${ }^{59}$ with a view to strengthening the Assembly's monitoring procedure. ${ }^{60}$

According to the Order, several Committees were charged with monitoring functions, including the Committee of Legal Affairs and Human Rights and the Political Affairs Committee. The Committee on Relations with Non-Member Countries was also involved in the process, releasing opinions concerning the Member States previously enjoying special guest status. ${ }^{61}$ These Committees had to report directly to the Assembly and were instructed to come up with draft Resolutions "in which clear proposals are made for the improvement of the situation in the country under consideration". ${ }^{62}$

The Order described a number of tools available to the Assembly to sanction poorly performing member countries. It outlined such tools as non-ratification of the credentials of a national parliamentary delegation at the beginning of the next ordinary session of the Assembly ${ }^{63}$ or addressing a recommendation to the Committee of Ministers to launch the procedure of Article 8 of the Statute of the $\mathrm{CoE}(\mathrm{SCoE}),{ }^{64}$ which is similar in effect to Article $7 \mathrm{EU}$ in the Union legal system and allows for the suspension of the rights of representation of the state violating its obligations. Unlike its EU counterpart, Article $8 \mathrm{SCoE}$ even allows for a request to withdraw from the CoE. Importantly, "if such member does not comply with this request, the Committee [of Ministers] may decide that it has ceased to be a member of the Council as from such date as the Committee may determine". ${ }^{65}$ Without any doubt, the positive outcome of the monitoring process under Order No. 508 was vital for the continuation of any given state's membership in the organisation.

In 1997, Order No. 508 was substituted with Resolution 1115 which created a special PACE Committee on the Honouring of Obligations and Commitments by Member States of the CoE (Monitoring Committee), ${ }^{66}$

\footnotetext{
58 Committee of Ministers of the Council of Europe, Declaration of 10 October 1994.

59 PACE Order No. Dir. 508 On the Honouring of Obligations and Commitments by Member States of the Council of Europe, Assembly debate on 26 April 1995 (12th Sitting).

60 PACE Order No. Dir. 508, para 5.

${ }^{61}$ PACE Order No. Dir. 508, para 6.

62 PACE Order No. Dir. 508, para 8.

${ }^{63}$ PACE Order No. Dir. 508, para 9.

${ }^{64}$ PACE Order No. Dir. 508, para 10.

${ }^{65}$ Statute of the Council of Europe art 8.

66 PACE Res. 1115(1997).
} 
concentrating the efforts of the Assembly and raising the monitoring task to a new level. According to the Resolution,

The Monitoring Committee [is] responsible for verifying the fulfilment of the obligations assumed by the member states under the terms of the Council of Europe Statute, the European Convention on Human Rights and all other Council of Europe conventions to which they are parties, as well as the honouring of the commitments entered into by the authorities of member states upon their accession to the Council of Europe. ${ }^{67}$

In other words, among other functions, the Monitoring Committee of PACE plays a role parallel to that played by the European Commission in the EU framework - the monitoring of the newcomers. Once again, the crucial difference between the EU and the $\mathrm{CoE}$ approach to monitoring is that in the EU the monitoring is done by the Commission prior to the candidate countries' accession to the Union, while in the CoE the monitoring 'should not commence until six months after the member state's accession to the Council of Europe'. ${ }^{68}$

According to Order No. 508, the Monitoring Committee's task (apart from the release of annual reports on its activities ${ }^{69}$ ) is to draft an official Assembly document - either a Resolution or a Recommendation as a result of the monitoring process of a given country. ${ }^{70}$ Before the authorities of the monitored country give a response to the findings of the Committee, these findings remain confidential. ${ }^{71}$

Since the adoption of Resolution 1115, the load of the Monitoring Committee has been considerable. Among other states, all the EU candidate countries from Central and Eastern Europe have been monitored.

The process of the monitoring of certain CEECs started and was successfully closed even before Resolution 1115 was adopted, under the auspices of Order No. 508. Thus, the monitoring of Estonia ${ }^{72}$ and Romania $^{73}$ was closed in 1997.

\footnotetext{
67 PACE Res. 1115 (1997), para 5.

68 PACE Res. 1115 (1997), para 4.

69 Released in accordance with PACE Res. 1115 (1997), para 12. See PACE Doc. 8057; PACE Res. 1155 (1998); PACE Rec. 1366 (1998); PACE Doc. 8359; PACE Doc. 8734; PACE Doc. 9198; PACE Res. 1260 (2001); PACE Rec. 1536 (2001) and PACE Doc. 9651.

70 Parliamentary Assembly of the Council of Europe, Terms of Reference of the Assembly Committee on the Honouring of Obligations and Commitments by Member States of the Council of Europe (Monitoring Committee), appended to Resolution Res. 1115 (1997), para 6.

${ }^{71}$ Res. 1115 (1997), Appended Terms of Reference, para 8.

72 Resolution Res. 1117 (1997) on the honouring of obligations and commitments by Estonia, Assembly debate on 30 January 1997 (7th Sitting). See also Recommendation Rec. 1313 (1997) on the honouring of obligations and commitments by Estonia, Assembly debate on 30 January 1997 (7th Sitting).

${ }^{73}$ Res. 1123 (1997); Rec. 1326 (1997).
} 
The closure of the monitoring procedures does not mean, however, that everything is perfect in a given $\mathrm{CoE}$ member country. The CoE Parliamentary Resolution closing the monitoring is usually accompanied by a Recommendation outlining the main issues to be resolved, giving the member country one year to address them. The Resolutions also warn the member countries that monitoring can be reopened anytime if the progress made is insufficient. ${ }^{74} \mathrm{~A}$ follow-up dialogue is also proposed to address pending issues of importance. ${ }^{75}$

A significant number of documents followed the start of the monitoring procedures in accordance with Resolution 1115: the monitoring of the Czech Republic ${ }^{76}$ and Lithuania ${ }^{77}$ was closed in 1997, and that of Slovakia ${ }^{78}$ in 1999. In 2000, the monitoring of Bulgaria ${ }^{79}$ and Croatia ${ }^{80}$ was closed. The closure of the monitoring of Latvia ${ }^{81}$ followed in 2001.

The Resolutions and Recommendations issued by the Parliamentary Assembly of the CoE usually touch the same issues as the Reports released by the Commission. ${ }^{82}$ It is unfortunate that the Commission only briefly mentions the closure of the $\mathrm{CoE}$ monitoring of the candidate countries in its Reports, without outlining the list of issues which can give rise to the re-opening of the monitoring procedure according to the Monitoring Committee. It seems that the general reporting by the European Commission could only win from paying more attention to the findings of the $\mathrm{CoE}$. This also concerns the possibility of Reporting on the follow-up procedures, which address issues of great importance. Only when both the Parliamentary Assembly monitoring and follow-up procedures are closed can the country in question be fully recognised as respecting its obligations stemming from $\mathrm{CoE}$ membership.

In other words, the findings of the $\mathrm{CoE}$ organs are regarded by the European Commission as valuable sources of information, but this information is not fully used by the EU. The mentioning of several ECtHR cases and the observation that the monitoring of several candidate countries is closed can only be viewed as half-hearted use of valuable expert information concerning the same issues as those assessed in the Com-

\footnotetext{
${ }^{74}$ See e.g. Res. 1123 (1997), para 15.

${ }^{75}$ Recently, dialogue has been concluded with regard to Estonia, Lithuania, Romania, Latvia and Croatia.

${ }^{76}$ Rec. 1338 (1997); Doc. 7898. The procedure was started under Order Dir. 508.

77 Rec. 1339 (1997); Doc. 7896.

${ }^{78}$ Rec. 1419 (1999); Res. 1196(1999) and Doc. 8496.

79 Res. 1211 (2000); Rec. 1442(2000) and Doc. 8616. Cf. 1997 Report Doc. 8180.

80 Doc. 8823; Res. 1223; Rec. 1473. Cf. 1999 Report Doc.8353; Res. 1185; Rec. 1405.

81 Doc. 8924; Res. 1236 (2001); Rec. 1490 (2001). Cf. 1999 Report Doc. 8426.

82 See IV.a, infra.
} 
mission's Reports. The Commission's Reports could only improve if the $\mathrm{CoE}$ experience were used better. Making such improvement a reality is certainly possible in the nearest future. With the necessary commitment on the part of the Commission and other institutions, the next enlargement could see PACE monitoring better included in the candidate countries' progress assessment.

\section{b. Monitoring administered by the Committee of Ministers}

Although the Committee of Ministers is not directly mentioned by the Commission in the Copenhagen-related documents, it is necessary to briefly outline the role it plays in the CoE monitoring system, since it can be involved in the imposition of sanctions (up to exclusion from the $\mathrm{CoE}$ ) on the countries found by the Parliamentary Assembly to be in violation of human rights.

There are three main areas of activity of the Committee of Ministers which are related to the post-accession monitoring of the new member countries. Firstly, the Committee of Ministers possesses certain powers related to the supervision of the execution of the decisions of the ECtHR under Article 46(2) ECHR. Secondly, it acts to improve the system of human rights monitoring. For example, it entrusted the Secretary-General of the $\mathrm{CoE}$ with monitoring functions under the 1994 Declaration on Compliance with Commitments Accepted by the Member States of the $\mathrm{CoE} .{ }^{83}$ Even without being entirely new to the $\mathrm{CoE}$ human rights protection system (since the Secretary-General has similar powers under Article 52 ECHR), ${ }^{84}$ this area of the Committee of Ministers' activity is really important, as the Committee can presumably go further in modifying the current system to improve its performance. Thirdly, the Committee of Ministers plays a key role in implementing the "last resort" measures to make the deviant members of the CoE comply with their obligations and commitments as $\mathrm{CoE}$ member countries. The Committee can suspend a country's representation in the $\mathrm{CoE}$ organs or even go as far as to request a country's withdrawal from the $\mathrm{CoE}$, according to Article $8 \mathrm{SCoE}$. Without mentioning the role played by the Committee of Ministers in the $\mathrm{CoE}$ system, the Commission pays attention to the monitoring of the candidate countries by the Parliamentary Assembly, which can theoretically

\footnotetext{
${ }^{83}$ Council of Europe, Declaration on Compliance with Commitments Accepted by Member States of the Council of Europe, Adopted by the $95^{\text {th }}$ session of the Committee of Ministers, 10 November 1994, para 1.

${ }^{84}$ Convention for the Protection of Human Rights and Fundamental Freedoms, art 52 (ex. art 57, before Protocol No. 11 amendments) reads as follows: "On receipt of a request from the Secretary General of the Council of Europe any High Contracting Party shall furnish an explanation of the manner in which its internal law ensures the effective implementation of any of the provisions of the Convention".
} 
result in the use by the Committee of Ministers of Article $8 \mathrm{SCoE}$ upon the request of the Assembly.

\section{c. Other bodies with monitoring functions}

A number of other $\mathrm{CoE}$ bodies entrusted with human rights monitoring functions have not been mentioned in the Commission's Opinions and Reports. Among these bodies is the European Committee of Social Rights (ECSR), ${ }^{85}$ reviewing the states' reports on compliance with the European Social Charter. The same Committee reviews collective complaints allowed for by the Additional Protocol to the European Social Charter concerning the system of collective complaints. However, according to Shelton, there were no collective complaints submitted from the ten new EU Member States throughout the time of the Commission's reporting (by 2003). ${ }^{86}$

Equally, the Commission's documents contain no reference to the activities of the Committee for the Prevention of Torture (CPT) ${ }^{87}$ The CPT functions by rendering visits to places of detention of any kind. Although concrete reports of the CPT are confidential, ${ }^{88}$ its annual reports might have been useful for the assessment of the situation in the candidate countries' prisons.

Another monitoring organ whose findings are not referred to in the Commission's assessments is the European Commission against Racism and Intolerance (ECRI). ${ }^{89}$ The mandate of the Commission includes tasks to 'review member States' legislation, policies and other measures to combat racism, xenophobia, anti-semitism and intolerance, and their effectiveness; propose further action at local, national and European level; formulate general policy recommendations to member States and study international legal instruments applicable in the matter with a view to their reinforcement where appropriate". ${ }^{90}$

\footnotetext{
${ }^{85}$ European Social Charter art 25. See also of the 1991 Protocol art 3, which was given interim application by the $\mathrm{CoE}$ and changed the name of the Committee of experts and the number of experts on the Committee: Council of Europe, Protocol Amending the European Social Charter, 21 October 1991, ETS No. 142, not in force. $C f$. D Shelton, 'The Boundaries of Human Rights Jurisdiction in Europe' (2003) 13 Duke J. Comp. \& Int'l L. 102 et seq.

${ }^{86}$ D Shelton (n 85) 105.

${ }^{87} \mathrm{Cf}$. European Committee for the Prevention of Torture and Inhuman or Degrading Treatment or Punishment <http://www.cpt.coe.fr> accessed 18 September 2006.

${ }^{88}$ European Convention for the Prevention of Torture and Inhuman or Degrading Treatment or Punishment art 10(1).

89 Established according to the Vienna Declaration of the Council of Europe, 9 October 1993, Appendix III, Plan of Action, para 3. Cf. the website of the European Commission against Racism and Intolerance <http://www.coe.int/T/E/human_rights/Ecri/> accessed 18 September 2006.

90 Vienna Declaration of the Council of Europe, 9 October 1993, Appendix III, Plan of Action, para 3.
} 
To summarise, the complex human rights monitoring system created by the $\mathrm{CoE}$, while serving goals similar to those of the EU pre-accession monitoring in the sphere of human rights protection, is built along different lines and is structurally more complicated than the EU pre-accession monitoring system. The number of references the Commission made to the findings of the CoE monitoring system is really minimal.

Apart from statements that the PACE monitoring of certain candidate countries is over (such information does not even appear in the context of the assessment of all the candidate countries' applications), the Commission appears unwilling to go into the details of the recommendations given by the $\mathrm{CoE}$ monitoring organs. Moreover, the Regular Reports released by the Commission in the course of the pre-accession exercise do not contain any information concerning the follow-up dialogue. By not including the follow-up dialogue, the Commission partially distorts the actual account of the state of play of human rights protection in the candidate countries, since new monitoring can be opened on the grounds of unfavourable follow-up reports. In other words, reporting that the PACE monitoring of a country is over only reflects half of the picture.

Realising the usefulness of using the results of the CoE bodies monitoring programmes, the recent report on $\mathrm{EU}-\mathrm{CoE}$ relations, written by Prime Minister Juncker of Luxembourg (in his personal capacity) ${ }^{91}$ following the request of the heads of states and governments of the $\mathrm{CoE},{ }^{92}$ recommended that an attempt be made to formally incorporate the $\mathrm{CoE}$ monitoring system within the EU enlargement law. ${ }^{93} \mathrm{He}$ stated, inter alia, that

It would [...] seem appropriate to me that EU bodies should give formal effect to the spirit of article 6(2) of the Treaty on the European Union, on which co-operation with the Council of Europe is based, by making it a working rule that the decisions, reports, conclusions, recommendations and opinions of these monitoring bodies:

1. will be systematically taken as the first Europe-wide reference for human rights;

2. will be expressly cited as a reference in documents which they produce. ${ }^{94}$

The Prime Minister also clarified that his proposals amounted to nothing more than recognition of the existing practice adopted by the

\footnotetext{
${ }_{91}$ JC Juncker (n 4).

${ }^{92}$ Warsaw Declaration of the Council of Europe, 17 May 2005, Action Plan, para 4.1 point 3.

${ }^{93}$ The European Council welcomed the Report and opined that it deserves "further consideration”. Brussels European Council Presidency Conclusions, 15-16 June 2006, para 58.

94 JC Juncker (n 4) 6.
} 
Commission and other institutions, ${ }^{95}$ which is confirmed by an analysis of the preparation for the last enlargement. ${ }^{96}$ Interestingly, Juncker's proposal was not solely confined to the PACE-conducted monitoring, but also concerned the monitoring conducted by other CoE bodies, as described above. ${ }^{97}$ In other words, the idea of making wider use of the CoE expertise in the course of the preparation of EU enlargements is gaining in importance.

\section{The issue of standard setting: Importance of the CoE monitoring system for the EU}

$\mathrm{CoE}$ monitoring was particularly important for the EU during the preparation for the last enlargement because of the timing when it was conducted: it started years before the release in 1997 of the Commission's Opinions on the candidate countries' applications for membership of the EU (de facto launching the Regular Reporting exercise).

It can be argued that the $\mathrm{CoE}$ monitoring wins in comparison with the monitoring conducted by the EU due to the presence of a clear and understandable human rights protection standard in the CoE system, as reflected, mostly, in ECHR and the jurisprudence of the ECtHR. Such a standard is certainly lacking in the EU, which is only guided by the principles of the ECHR, as reflected in Article 6(2) EU. ${ }^{98}$ The Convention in itself, although possessing "special significance", 99 is merely a source of general principles, to be applied in the context of the Treaty Provisions. ${ }^{100}$ Moreover, having no general competence as far as human rights protection is concerned, ${ }^{101}$ the EU, legally speaking, could not have such a standard.

Stunningly, this problem seems to have been totally ignored by the Commission in the documents it released in the course of regular reporting. In six Opinions on the candidate countries' applications for member-

\footnotetext{
95 Ibid

${ }^{96}$ See IV., infra.

97 JC Juncker (n 4) 5.

98 The first reference to the Convention in the texts of the Treaties appeared in the Preamble to the SEA and was acknowledged by the ECJ in Case 249/86 Commission v Germany [1989] ECR 1263, para 10.

${ }^{99}$ For example, Case C-299/95 Kremzow v Austria [1997] ECR I-2629, para 14; Opinion 2/94 on Accession by the Community to the ECHR [1996] ECR I-1759, para 33; Case C260/89 ERT v DEP [1991] ECR I-2925, para 41.

100 See, for example, Case C-185/97 Coote v Granada Hospitality Ltd. [1998] ECR 5199, paras 21-23; Case C-13/94 Pv S [1996] ECR I-2143, para 18; Case 22/84 Johnston v Chief Constable of the Royal Ulster Constabulary [1986] ECR 1651, para 18. Cf. Opinion of Trabucchi AG in Case 118/75 Watson \& Belmann [1976] ECR 1185, 1207.

101 Opinion 2/94 on Accession by the Community to the ECHR [1996] ECR I-1759.
} 
ship of the Union, the Commission went as far as to state that "the European Convention for the Protection of Human Rights and its principal additional protocols [...] form part of the "acquis communautaire" by virtue of a reference made to the Convention in Article 6(2) EU [ex. Art. F]. ${ }^{102}$ This statement is simply false and can only be applied to the principles of the Convention interpreted in conjunction with the norms of Community law. In other words, having general principles at hand, the EU still lacked a concrete standard to be applied in the course of pre-accession. The same is valid for the Charter of Fundamental Rights of the EU. Let alone its ambiguous status as a proclaimed document, ${ }^{103}$ according to Articles $51(2)$ and 54, it clearly does not apply to situations (including human rights violations) deemed to lie outside the scope of Community law. ${ }^{104}$

The Commission, perfectly aware of the lack of a general human rights protection standard uniformly applied to all the applicants in the course of pre-accession, never recognises that such a standard is missing, since it speaks about a "European standard". This capacity of the Commission to turn a blind eye to the limitations inherent in its position has prompted scholars to regard this institution as a prolific myth-maker. ${ }^{105}$ While possessing no human rights standard, it did its best to convince the candidate countries that such a standard did exist, although it never gave them a chance to see it on paper.

Since the lack of Community competence in a given sphere does not mean that certain elements pertaining to this sphere cannot be assessed in the course of pre-accession, the creation of a standard like this does not per se contradict Community law. The date of a country's accession to the EU serves as a watermark here. As long as a given country is not a Member State, the Union is not bound by the limitations of competence applicable to its relations with the Member States and is thus free to act as it sees fit. For example, the Union pressured Latvia and Estonia to

102 Commission's Opinions on the Czech application, 13; on the Estonian application, 16; on the Hungarian application, 17; on the Lithuanian application, 15; on the Slovak application, 19; on the Bulgarian application, 15; on the Slovenian application, 18.

${ }^{103}$ For an interesting perspective on what it might mean, see K Lenaerts and E de Smijter, 'A Bill of Rights for the EU' (2001) 38 CML Rev 90, fn. 1 (comparing a solemn proclamation to an insertion into the Treaty).

${ }^{104}$ For an analysis, see A Knook, 'The Court, The Charter, and the Vertical Division of Powers in the European Union' (2005) 42 CML Rev 367, E Vranes, 'The Final Clauses of the Charter of Fundamental Rights - Stumbling Blocks for the First and Second Convention' (2003) 7(7) EIoP <http://eiop.or.at/eiop/texte/2003-007.htm> accessed 18 September 2006 .

105 See Smilov's brilliant paper (focusing on the pre-accession promotion of judicial independence). D Smilov, 'EU Enlargement and the Constitutional Principle of Judicial Independence' (delivered at the workshop 'Implications of Enlargement for the Rule of Law, Democracy and Constitutionalism in Post-Communist Legal Orders', EUI Florence 28-29 November 2003) <www.iue.it> accessed 18 September 2006. 
amend their naturalisation legislation and achieved certain (albeit very limited) success in this exercise. ${ }^{106}$ However, had Latvia and Estonia been EU Member States at the time when such pressure was exercised, the Union would not have stood any chance, since national citizenship regulation generally falls outside the scope of EU competences, as confirmed by the ECJ in the Micheletti case. ${ }^{107}$

In other words, the lack of general human rights competence vis-àvis the Member States could not prevent the Commission from elaborating a human rights standard for the acceding countries. The principle of conditionality and all the regular reporting exercises were something new to the EU enlargement practice. Consequently, the Commission could not draw on the experience of past enlargements as far as the human rights protection standard was concerned. The standard had to be created. Ultimately, the Commission ended up doing precisely this: it created a standard of human rights assessment in the candidate countries. However, since the EU did not appear to be willing to acknowledge that it did not have any standard of human rights protection at hand when the regular reporting started, neither was such a standard promulgated by the European Commission in the course of the previous enlargements (the Copenhagen criteria, being overbroad and extremely vague, can hardly qualify as a road-map for reform in the sphere of human rights protection or for the assessment of progress made by the candidate countries), such a standard was only created in the course of the assessment of the applicant countries' requests for membership of the EU. As a consequence, lacking in generality and consistency, the standard, which can be read between the lines of the Copenhagen-related documents, is mostly related to the concrete problems of the candidate countries.

At the same time, while dealing with European countries wishing to accede to the EU, the Commission's experts did not need to travel far around the continent for sources of inspiration. The Strasbourg human rights protection system, rightly considered by many to be the most advanced in the world, was clearly the most suitable tool.

\section{The borrowing of $\mathrm{CoE}$ findings by the $\mathrm{EU}$ in the course of pre- accession}

Prime Minister Juncker was absolutely right in claiming that the use of $\mathrm{CoE}$ findings by EU institutions is a day-to-day reality. Analysis of the

\footnotetext{
${ }^{106}$ D Kochenov, 'Pre-accession, Naturalisation and "Having Due Regard to Community Law": The European Union's 'Steering' of National Citizenship Policies in the Candidate Countries in the Course the Fifth Enlargement' (2004) 4 Romanian J. Pol. Sci. $71<$ http:// ssrn.com/abstract=926851 > accessed 18 September 2006.

107 Case C-369/90 Micheletti v Delegación del Gobierno en Cantabria [1993] ECR I-4239, para 10.
} 
substance of the Opinions on the Application for Accession to the EU and Regular Reports on the Candidate Countries' Progress towards accession released by the Commission demonstrates that the CoE standards have on some occasions been adopted as cornerstones of the Commission's assessment of the pre-accession progress achieved by the candidate countries in the field of human rights protection. Similarly, requests to conduct reforms in certain areas included in the Accession Partnerships are often identical to the recommendations made some time earlier by the $\mathrm{CoE}$ Committee of Ministers, ${ }^{108}$ although no reference to the $\mathrm{CoE}$ experience is made.

Unable to assess the whole spectrum of human rights protection issues included by the Commission in the Copenhagen-related documents (which is the subject for a book, not a brief note like this), the paper will concentrate on several issues where the influence of the $\mathrm{CoE}$ and the commission have acted together to resolve human rights problems in the candidate countries. The similarities between what the $\mathrm{CoE}$ and the $\mathrm{Eu}-$ ropean Commission recommend are very telling.

Comparing the Copenhagen-related documents and the documents issued earlier in relation to the CoE's monitoring of the same countries, two levels of similarity can be outlined:

a) The general level - i.e. the similarities concerning the lists of issues outlined as problematic and requiring action;

b) The issue-specific level - mostly consisting of recommendations issued by the $\mathrm{CoE}$ and the $\mathrm{EU}$ organs to deal with the same issue appearing on the list.

\section{a. Borrowing at the general level}

The similarities between the EU and CoE monitoring are most evident at the general level - which is also the most important one, since in order to solve problems effectively it is necessary first to outline their scope. To see the similarities better, consider the issues listed as "problematic" by the $\mathrm{CoE}$ and the $\mathrm{EU}$ in relation to the reforms going on in two countries: Romania and Estonia. The choice of these countries is not by chance: first and foremost, these are the only two countries in relation to which the $\mathrm{CoE}$ monitoring was finished by the time the European Commission released its Opinions on their application for Membership of the

108 For country by country CoE monitoring, see PACE Resolutions Res. 1117 (1997); Res. 1123 (1997); Res. 1196 (1999); Res. 1211 (2000); Res. 1223 (2000); Res. 1185 (2000); Res. 1236 (2001); PACE Recommendations Rec. 1313 (1997); Rec. 1326 (1997); Rec. 1338 (1997); Rec. 1339 (1997); Rec. 1419 (1999); Rec. 1442 (2000); Rec. 1405 (2000); Rec. 1473 (2000); Rec. 1490 (2001) and a number of PACE Reports: Doc. 7898; Doc. 7896; Doc. 8496; Doc. 8616; Doc. 8180; Doc. 8823;. Doc. 8353; Doc. 8426; Doc. 8924, etc. 
EU. ${ }^{109}$ Secondly, the pace of reform in these countries differed greatly, ultimately resulting in the admission of Estonia to the EU in May 2004, while Romania is an acceding country.

In the case of Romania, CoE monitors outlined a number of issues of concern. PACE Resolution 1123 (1997) on the Honouring of Obligations and Commitments by Romania, and PACE Recommendation 1326 (1997) on the Honouring of Obligations and Commitments by Romania drew attention to the need for reform in the following areas: independence of the judiciary; ${ }^{110}$ the rights of homosexuals; criminalisation of insult and defamation; ${ }^{111}$ the situation in prisons; ${ }^{112}$ the situation of children in orphanages; ${ }^{113}$ restitution of property; ${ }^{114}$ Roma rights and the fight against racism and xenophobia. ${ }^{115}$ If improvements were not made in these areas, monitoring would have to be reopened. ${ }^{116}$

The Opinion on Romania's application for membership of the EU, issued by the European Commission roughly half a year after the $\mathrm{CoE}$ closed its monitoring, focused inter alia on the following issues: problems related to the penalties laid down in the Criminal Code for false reporting and defamation; ${ }^{117}$ restitution of property to the churches and to Jewish organisations; ${ }^{118}$ lack of respect of privacy; unsatisfactory access of asylum seekers to justice and accommodation; poor conditions in the coun-

109 The Commission's Opinions concerning these countries' applications were released on 15 July 1997, together with Agenda 2000 (COM(2000) 97 final), while the CoE documents finishing the monitoring appeared on 30 January 1997 (PACE Res. 1117 (1997); Rec. 1313 (1997); Res. 1123 (1997); Rec. 1326 (1997)). It is necessary to underline that the CoE released a number of general documents focusing on different human rights violations - not specifically pointing at those countries where such violations mostly occur. Thus, the main problematic areas for all the $\mathrm{CoE}$ member countries were made known before the European Commission started its own monitoring. Romania and Estonia are not the only two countries where information concerning the human rights situation could be easily available to the European Commission.

110 PACE Res. 1123 (1997), para 8; the request to amend the Judiciary Act is contained in para 14(i).

111 PACE Res. 1123 (1997), para 9.

112 PACE Res. 1123 (1997), para 10; request to amend the legislation is contained in para 14(ii). PACE Rec.1326 (1997), para 2(i).

113 PACE Res. 1123 (1997), para 11; request to address the problem, including amending the relevant legislation is contained in para 14(iii). Further recommendations: PACE Rec.1326 (1997), para 2(ii).

114 PACE Res. 1123 (1997), para 12; request to amend the relevant legislation is contained in para 14(iv).

115 PACE Res. 1123 (1997), para 13, making a reference to PACE Rec. 1201 (1993). The request to promote the social integration of the Roma is contained in para $14(\mathrm{v})$. PACE Rec.1326 (1997), para 2(iii).

116 PACE Res. 1123 (1997), para 15.

117 European Commission, Romanian Opinion, 16.

118 Ibid 
tries' prisons; 119 abuses of homosexuals' rights through the vague Criminal Code provision dealing with "public scandal"; ${ }^{120}$ the critical situation regarding the rights of the child, ${ }^{121}$ which "may improve shortly"; ${ }^{122}$ the situations of the Hungarian and Romanian minorities. ${ }^{123}$ In the following years, the Commission's assessment generally moved along similar lines, following the path opened by the CoE.

Even more importantly, the issues outlined by the $\mathrm{CoE}$ made their way into the Accession Partnerships with Romania. The first one, released in 1999, for example, included among the short-term priorities the issue of the necessary reform of childcare institutions and Roma rights, ${ }^{124}$ and repeated the same concerns (coupled with the demilitarisation of the police) among the mid-term priorities. ${ }^{125}$

Thus, it is clear that the issues outlined by the CoE and those outlined by the European Commission concerning the situation with the protection of human rights in Romania are very similar.

An analogous situation can be observed in relation to the monitoring of Estonia's reform by the EU and the CoE. PACE Resolution 1117 (1997) on the Honouring of Obligations and Commitments by Estonia, and PACE Recommendation 1313 (1997) on the Honouring of Obligations and Commitments by Estonia focused on the following aspects of Estonian reform: violations of asylum-seekers' rights and the lack of asylum procedures; ${ }^{126}$ maltreatment of the Russian-speaking minority in Estonia, especially the problems related to the granting of residence permits and citizenship; ${ }^{127}$ state-funded Russian-language education ${ }^{128}$ and the better teaching of Estonian to Russian speakers; ${ }^{129}$ the conditions of custody and detention. ${ }^{130}$ Also, in line with Recommendation 1302 (1996) on the Abolition of lease of the Opinion. See, for example, the Regular Reports on Romania's progress towards accession to the Union of 1998 and 199910 et seq. and 15 et seq. respectively. Moreover, Child Protection becomes a special heading in the Commission's 1999 Report on Romania's progress towards accession - a unique structural change, unknown to all other Reports released by the Commission, which certainly underlines the importance of this issue.

${ }^{123}$ Romanian Opinion (n 121), 18.

${ }^{124}$ Council Decision - first accession partnership with Romania, Annex, point 4.1.

125 Ibid, point 4.2 .

${ }^{126}$ PACE Res. 1117 (1997), para 5; recommendations contained in para 8(i).

127 PACE Res. 1117 (1997), para 6; recommendations contained in para 8(ii).

128 PACE Res. 1117 (1997), para 8(iii).

129 PACE Rec. 1313 (1997), para 2(iii).

130 PACE Res. 1117 (1997), para 7; recommendations contained in para 8(iv) and Rec. 1313 (1997), para 2(i).
} 
the Death Penalty in Europe, PACE recommended the abolition of capital punishment in Estonia. ${ }^{131}$

The Commission, in turn, focused, among other things, on the following aspects of Estonian reform: ${ }^{132}$ the fact that capital punishment had not been abolished in Estonia; ${ }^{133}$ the lack of access to legal aid; ${ }^{134}$ the ill-treatment of prisoners, although mention was made of some steps forward in relation to the treatment of asylum-seekers. ${ }^{135}$ A relatively large section of the Opinion was devoted to the situation of the Russian-speaking minority in Estonia, ${ }^{136}$ focusing on the differences in the status of citizens and non-citizen residents, problems of the integration of the minority and, specifically, linguistic integration. As if to better reflect the stress placed by the CoE, further Reports by the Commission introduced a special structural arrangement of information contained in sections devoted to the assessment of minority protection in Estonia, reserving special sections for an assessment of the naturalisation of non-citizens and the granting by the authorities of residence-permits to non-citizens. ${ }^{137}$ Just as in the case of most of the other Opinions and Reports released by the European Commission, the work done by PACE is not mentioned at all.

A comparison of the issues outlined by the Commission in the course of the pre-accession exercise and by the $\mathrm{CoE}$ in the course of the PACE monitoring addressed in the context of reforms progressing in other countries of the region reveals precisely the same level of similarity. This is not to say that the sets of issues are identical. Nevertheless, the fact that the majority of the issues addressed coincides seems to be of importance.

\section{b. Borrowing at the issue-specific level}

The situation changes slightly once one moves from the general comparison of the sets of issues outlined by the EU and by the $\mathrm{CoE}$ as problematic to the area of the remedies proposed by the two. While placing issues on the agenda is extremely important, the importance of providing ways to deal with the problems outlined is also essential. Strange as it may seem, the Commission does not appear to be very willing to provide

\footnotetext{
131 PACE Rec. 1313 (1997), para 2(ii).

132 Just as in the case of Romania, for the lack of space, the author does not provide an account of those aspects of human rights protection which the European Commission did not consider problematic.

${ }^{133}$ European Commission, Opinion on Estonia's application for membership of the European Union, 16.

${ }^{134}$ Ibid

135 Ibid, 17.

136 Ibid, 17-20.

137 See: European Commission, Regular Reports on Estonia's progress towards accession to the European Union of 1998 and 1999.
} 
remedies to deal with problems in the candidate countries. Moreover, it is generally not very demanding, mostly confining its Reporting to the changes implemented in the candidate countries, often without accompanying it with any assessment - negative or positive. Even more importantly, the assessment of the Copenhagen-related documents seems to suggest that the human rights related issues which do not constitute part of the acquis communautaire are less likely to be included in the Accession Partnerships and thus are not promoted actively by the Commission (probably the most notable exception being the treatment of minorities, and especially of the Roma). Sometimes, the Commission's demands that fall outside the scope of the acquis remain unmet by the candidate countries, notwithstanding their inclusion among the priorities of the accession partnerships. ${ }^{138}$

Generally, such a situation is not surprising. Having chosen problematic areas in the human rights protection in the candidate countries in general (with no regard to whether a certain issue falls within the scope of the acquis or not), the Commission needed to take a step further to promote reforms in these specific fields. However, lacking the general human rights protection standard, it was unable to provide effective guidance to the candidate countries in the areas which were not part of the acquis, since, understandably, the Commission mostly enjoys expertise and in-depth knowledge of the issues situated within the scope of the acquis and not other issues - especially those which are almost totally outside the acquis, such as, for example, the establishment of the post of Ombudsman or non-discrimination in the course of the restitution of property. ${ }^{139}$ These instances once again demonstrate that however broadly interpreted it is, the scope of the acquis still remains limited.

Frequently basing its Reporting in the spheres lying outside the scope of the acquis on the findings of the $\mathrm{CoE}$ and on the documents

\footnotetext{
${ }^{138}$ The lack of success in the Commission's promotion of the adoption of the law on the restitution of property in Poland can serve as an excellent example: the issue appeared in a number of Copenhagen-related documents, but Poland entered the European Union without such legislation. Another example is the totally unsuccessful promotion of the post of ombudsman in Bulgaria: started in 1997, it has been absolutely fruitless. $C f$. respectively: M Karadjova, 'Property Restitution in Eastern Europe: Domestic and International Human Rights Law Responses' (2004) 29 Review of Central and East European Law 3; N Ananieva and M Yordanova, Istitutzijata Ombudsman $v$ Evropa i B lgarija: pravna s štnost i praktika (Tzentr za izsledvane na demokratzijata, Sofija 2004).

139 The restitution of property threatened to be an issue of ultimate importance for the Czech Republic, especially in relation to the restitution of the property of the Sudeten Germans confiscated under the Beneš decrees right after WWII. However, a board of experts concluded that the Treaties cannot apply to confiscations that happened so long ago. See JA Frowein, U Bernitz and Lord Kingsland, 'Legal Opinion on the Beneš-Decrees and the accession of the Czech Republic to the European Union' (European Parliament DG Research Working Paper PE323.934, 10-2002) para 17.
} 
released by this institution, the Commission usually adopts a part of the available CoE standard, sometimes diminishing the substance of the right whose protection it is entrusted to assure under the Copenhagen criteria. A huge number of examples can be provided to illustrate this statement. This note will concentrate on two: the first is the implementation by the Commission of the elements of PACE Recommendation 924 (1981) on Discrimination against Homosexuals in its reporting, ${ }^{140}$ and the second is the partial adoption of Recommendation of the CoE Committee of Ministers No. R (85) 13 on the Institution of the Ombudsman.

PACE Recommendation 924 (1981) was promoted by the Commission almost to the letter. The document called for the abolition of all forms of discrimination and recommended $\mathrm{CoE}$ members to conduct, among others, the following legal reforms (§ 7):

1. Decriminalisation of homosexual acts; $;{ }^{141}$

2. Application of the same minimal age of consent for homosexual and heterosexual acts; ${ }^{142}$

3. Abolishing the practice of keeping record of homosexuals by the police and other public authorities;

4. Assurance of equality of treatment of homosexuals with regard, in particular, to employment, pay and job security.

A little more than ten years after the release of Recommendation 924 (1981), PACE passed a Written Declaration addressing the protection of homosexuals' rights specifically in the CEECs. ${ }^{143}$ The Commission started promoting precisely these policies.

Before the inclusion of Article 13 in the EC Treaty of Amsterdam, the Community had no powers to deal with discrimination on the basis of sexual orientation. ${ }^{144}$ While at present Council Directive 2000/78/

\footnotetext{
${ }^{140}$ For more on the promotion of the non-discrimination on the basis of sexual orientation in the course of pre-accession, see D Kochenov, 'Democracy and Human Rights - Not for Gay People? EU Eastern Enlargement and its Impact on the Protection of the Rights of Sexual Minorities' Texas Wesleyan LR (forthcoming).

${ }^{141}$ Dudgeon v UK (App no 7525/76) (1983) prohibition of a flat ban on same-sex sexual acts. Discriminatory privacy laws are also prohibited by the ECtHR: Norris v Ireland (App no 10581/83) (1988); Modinos v Cyprus (App no 15070/89) (1993); A.D.T. v UK (App no 35765/97) (2000).

${ }_{142}$ Sutherland v UK (App no 25186/94) (2001) the age of consent should be the same for homosexual and heterosexual acts.

143 PACE Written Declaration No. 227 “Homosexual Rights in New Democracies”, Doc.6779, 18 February 1993.

144 'At present the Treaty on European Union does not confer specific powers on the institutions to eradicate discrimination on grounds of sexual orientation'. Answer given by Mr. Flynn on behalf of the Commission to Written Question No. 2224/96 by N van Dijk to the Commission: Coordination of Policy on Homosexual Men and Lesbian Women [1996] OJ C 356/95. Cf. answers to Written Questions No. 2133/83 (to the Council) and No. 2134/83
} 
$\mathrm{EC},{ }^{145}$ adopted in implementation of Article $13 \mathrm{EC}$, expressly states that any discrimination based inter alia on sexual orientation "will be prohibited", ${ }^{146}$ in recognition of the fact that "discrimination based on [...] sexual orientation may undermine the achievement of the objectives of the Treaty", ${ }^{147}$ the situation in this field was quite different when the Commission's regular reporting started. With the lack of prohibition of discrimination on the ground of sexual orientation, the issue has been treated indirectly, via rights to privacy and human dignity. ${ }^{148}$ Since the issue fell outside the scope of the acquis, the Union had no standard to measure the candidate countries' compliance with it. Moreover, the reporting started in an atmosphere where the ECJ refused to award protection to homosexuals discriminated on the grounds of their orientation. ${ }^{149}$ This fact was reflected in the way the Commission looks at this right in the pre-accession period.

The Opinions and Regular Reports released by the Commission focus on the following issues: decriminalisation of homosexual acts ${ }^{150}$ and the application of the same age of consent. ${ }^{151}$ The latter was a serious problem for the CEECs: according to the European Parliament, in the year 2000 discrimination based on the age of consent, for example, existed in Romania, Bulgaria, Estonia, Hungary and Lithuania. ${ }^{152}$ The Commission (probably following the ECJ judgement in the Grant case) never mentions the necessary guarantee of equality of treatment of homosexuals! The essence of the right was thus forgotten. Nevertheless, a partial adoption of the CoE standard in this field is evident. A parallel can be drawn between the Commission's use of the CoE documents and the ECJ, recognising the principles of the ECHR and interpreting them in the light of EC law, as it stands.

(to the Commission) by I van den Heuvel: Homosexuality [1984] OJ C 173/9 and [1984] OJ C $152 / 25$.

145 Council Directive (EC) 2000/78 of 27 November 2000 establishing a general framework for equal treatment in employment and occupation [2000] OJ L 303/16.

146 Council Directive (EC) 2000/78 art 1.

147 Preamble to Council Directive (EC) 2000/78 para 11

${ }^{148}$ Cases T-121/89 and 13/90 Xv Commission [1992] ECR II-2195; Case C-404/92P X v Commission [1994] ECR I-4780; Case T-10/93 A v Commission [1994] ECR II-179.

${ }^{149}$ Case C-249/96 Lisa Jacqueline Grant v South-West Trains Ltd. [1998] ECR I-621. Cf. J McInnes., 'Case C-249/96' (1999) 36 CML Rev 1043.

150 See Romanian Report 2001, 23 and preceding reports on Romania's progress towards accession. Opinion on Romanian Application, 16. A strange situation occurred: a state criminalising homosexual acts was announced to have satisfied the Copenhagen criterion of homosexuals' rights protection.

151 Bulgarian Report 2001, 22; Estonian Report 2001, 21; Hungarian Report 2002, 29.

152 Resolution on Respect for Human Rights in the European Union (1998-1999) [2000] OJ C 377/344, para 76 . 
This impression is further reinforced when one considers the other examples of the use of the $\mathrm{CoE}$ in the promotion of a specific issue of reform by the European Commission. Dealing with the promotion of the post of Ombudsman in the candidate countries, the Commission, once again, was faced with an issue falling outside the scope of the acquis. The fact that the EU, too, has an Ombudsman ${ }^{153}$ does not change the essence: it has no grounds to interfere in such aspects of institutional development in the Member States as the promotion of Ombudsman posts. During pre-accession, however, the Commission considered that putting "a well established Ombudsmen system"154 in place was a necessary step towards further democratisation. The same idea - that the Ombudsman is a necessary organ in a democratic state - has been promoted by the CoE since 1975, ${ }^{155}$ long before the European Ombudsman was put in place. The most important documents adopted by the CoE in the field are CM Recommendation No. R (85) 13 "On the Institution of the Ombudsman" of 23 September 1985 and a more detailed PACE Recommendation 1615 (2003) "The Institution of Ombudsman", adopted 18 years later. As usual, the Commission did not mention any of these documents in its Reports.

The approach to the issue taken by the $\mathrm{CoE}$ is more balanced compared to that adopted by the Commission. First of all, the CoE clearly promotes the creation of such posts in the $\mathrm{CoE}$ member states where it does not exist. Secondly, the CoE formulated a list of qualities the Ombudsman's office should possess in a democratic society, a task the Commission was unwilling to do. In other words, by promoting the creation of the Ombudsman post, but being silent on the essence of the organ, the Commission made the candidate countries turn, among other things, to the $\mathrm{CoE}$ experience in the field of Ombudsman promotion, which could clarify the essence of the Ombudsman's status and competences.

\section{Conclusion}

The systems of monitoring the compliance of the new member countries of the $\mathrm{CoE}$ and the candidate countries of the EU to their human rights commitments are similar in many respects. While the EU has elaborated a sophisticated pre-accession human rights monitoring system to effectively implement the principle of conditionality, the $\mathrm{CoE}$ system is no less advanced and is even superior to that of the EU in some re-

153 Art 195 EC and art II-43 TCE. See P Craig and G de Búrca, EU Law: Text, Cases and Materials (3rd edition OUP, Oxford 2003) 82-84. Cf. K Heede, European Ombudsman: Redress and Control at Union Level (Kluwer, The Hague /London /Boston 2000).

154 Lithuanian Report 2000, 19 (the Commission always uses a similar formula to praise the creation of the post).

155 PACE Recommendation Rec. 757 (1975), para 10 
spects. Most importantly, the system of standards employed by the $\mathrm{CoE}$ during its monitoring is much better articulated than that of the EU. These monitoring systems - one pre-, another post-accession - are largely complementary. Given that the $\mathrm{CoE}$ has already successfully enlarged to embrace the European continent almost in its entirety, it is up to the EU to benefit from the human rights standards devised by the leading human rights protection organisation in the world for its post-accession monitoring.

The cooperation between the two organisations is growing, as evidenced by the rising political interest in better dialogue between them. This interest is very well illustrated by the 2006 Juncker Report on EU - CoE relations commissioned by the 2005 CoE Warsaw summit and acknowledged by the European Council in Brussels (June 2006). The atmosphere of growing interest in cooperation provides solid ground for the open inclusion of the $\mathrm{CoE}$ monitoring results into the edifice of the EU enlargement law. Moreover, by building on the $\mathrm{CoE}$ standards and experience, the application of the conditionality principle in the field of human rights protection is likely to be made more effective and transparent.

Moreover, a move to enhance cooperation between the CoE and EU in this sphere would also mean the continuation of the processes that have already started in the course of the preparation of the fifth enlargement. In the fields where its expertise was lacking and clear human rights standards (elaborated by the EU) missing - most notably while dealing with those aspects of human rights protection that generally fall outside the scope of the acquis communautaire - the European Commission was already largely relying on the experience of the $\mathrm{CoE}$. This was done at two levels: at the general level of agenda setting and at the level of the promotion of concrete reforms and innovations.

Given the reality of the fifth enlargement, it becomes clear that a move towards a somewhat more formal incorporation of the $\mathrm{CoE}$ monitoring system within the EU pre-accession is already possible in the preparation for accession of the present candidate countries, i.e. Croatia, Macedonia and Turkey. Such a move will capitalise on existing practice, making the accession process more reliable and efficient. 
